Драгана Б. ВУКИЋЕВИЋ*

Универзитет у Београду

Филолошки факултет
Оригинални научни рад

Примљен: 16. 10. 2020.

Прихваћен: 25. 2. 2021.

\title{
ТРОМПЛЕЈСКА БИЋА ФИКЦИЈЕ
}

\begin{abstract}
У тематски фокус студије Тромплејска бића фикције смештени су специфични књижевни јунаци, другачији од осталих јер имају флуидан онтолошки статус; то су лиминални јунаци, а међе које прелазе су: рођени-нерођени, мртви-живи, нељудски-људски. Ови јунаци се не могу сместити у границе класичне аристотеловске миметичке концепције јунака (бољег, горег или попут нас) па се решење тражи у оквирима теорије могућих светова или когнитивне наратологије. У каталогу тромплејских јунака нашле су се бебе, вампири, оживела уметничка дела (статуе, портрети) али и тромплејски читалац који остаје заглављен у хипертекстуалном свету. Подстицај за именовање тромплејских бића везан је за ликовну технику која производи оптичку варку да насликани јунаци или ствари „излазе” из оквира слике и „улазе” у свет посматрача.
\end{abstract}

Кључне речи: тромплеј, лимес, вампири, оживљене статуе.

У студији, која се бави анализом књижевног текста, покушај да се под кров насловне синтагме Тромплејска бића фикиије сместе и дела из вербалне уметности може изазвати оправдану неверицу. Тромплеј је трик, оптичка варка којим се ствара илузија тродимензионалних објеката на дводимензионалној површини. Јавља се у ликовној уметности, архитектури, позоришној уметности, дизајну. У ликовној поетици, не само да означава ефекат обмане, већ је препознат и као жанр са дугом историјом. Тромплеј који је скренуо нашу пажњу односи се на слику шпанског сликара, илустратора и гравера Пере Борељ дел Каса (Pere Borrell del Caso) Бекство од критике. Иако насликана давне 1874, она спада у ред најцитиранијих тромплејских остварења. 


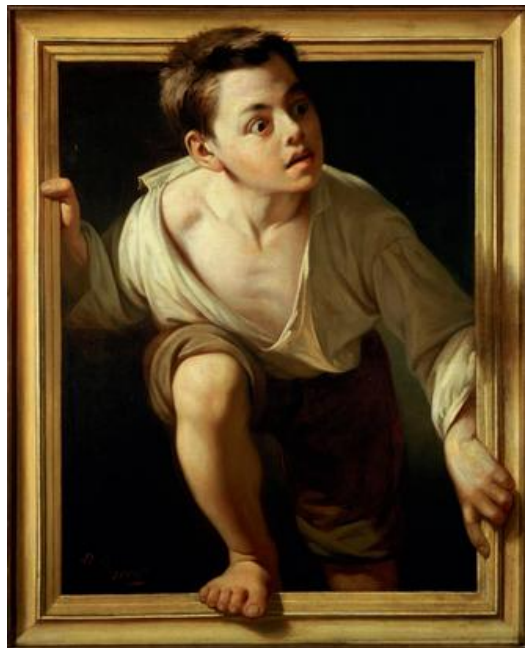

Escaping criticism, Pere Borrel del Caso ${ }^{1}$

Нашу пажњу није привукла ни техника (вештина) која твори илузију, нити несавршеност чула која омогућавају превару, већ „зачарана симулација” (како Бодријар назива тромплеје) $)^{2}$, ефекат објекта истовремено поринутог у две онтолошке, различите просторне и временске димензије.

Дечак који је кренуо из фикцијског универзума слике и покушао да изађе из онтолошког рама сопственог бића, усмерио нас је према фикцијском универзуму књижевних јунака. Ликовни жанр нас је инспирисао да трагамо за његовим књижевним панданима: за бићима која су у књижевној фикцији остварила „тромплејски” бивалентан онтолошки статус. Изворно значење речи везано за превару ока, усмерили смо ка неологизмима који имају шире значење: „trompe-fiction”, ,trompe-sens” и којима се могу обухватити сва фикцијска бића, било насликана или вербализована, која имају бивалантан онтолошки статус. Ипак, у наслову смо задржали познатији, одомаћен неологизам - тромплеј, свесни његовог суженог значења (превара ока наспрам превара свих чула). Тиме смо хтели да истакнемо везу са сликом Бекство од критике која нас је иницијално инспирисала, којом је наша прича о књижевним ,тромплејима” и започела, не бежећи од критике кумовања већ је свесно прихватајући.

О тромплејским бићима у књижевности почели смо да размишљамо пишући рад за научни скуп посвећен бебама и нашавши се пред загонетком бића које, слично дечаку на слици Пера Борељ дел Каса, овог пута пролазећи кроз „врата утробе”, излази из оквира једног света, и „улази”, најчешће с плачом, у други, наш свет. Иако су отворено поље аутоучитавања (не говоре

${ }^{1}$ Слику смо преузели са сајта са ознаком public domain: https://en.wikipedia.org/wiki/Pere Borrell_del_Caso\#/media/File:Escaping_criticism-by_pere_borrel_del_caso.png;

${ }^{2}$ Бодријар пише о порнографији као рашчараној симулацији и тромплејима као зачараним симулацијама (Бодријар, 1994). 
наш језик, али су стално поље наших означавања), бебе смо оставили у предвоју тромплеја одвајајући их од оних бића која не мењају само онтолошки статус у еволутивним развојним фазама - већ целокупно онтолошко стање. Било рођене или нерођене (фетуси) - бебе су живе. За разлику од оживљених мртваца или оживљених статуа, оне деле онтолошки рам својих означатеља и интегрисане су у њихов могући свет.

И док су бебе природне и могуће, прави тромплејски јунаци су немогући и неприродни јер живе истовремено у различитим онтолошким алтернитетима. Они, попут вируса, прелазе рампе светова; теку између живих и мртвих, нерођених и рођених, стварних и имагинарних, од крви и меса и оних од трулежи или од мермера. Најмањи заједнички садржатељ ових јунака јесте њихов бивалентан онтолошки статус, преступ и прелаз, лимес у којем као могући у немогућем, и као немогући у могућем егзистирају. Сваки од ових јунака спаја у себи неспојиве границе живог и неживог, живог и мртвог, умрлог и рођеног, речју, они су тачке парадоксалног ерототанатичног потирућег сусрета.

Тромплеје смо и нумерички означили. Бројем један - оживеле мртваце и вампире као њихову типску варијацију. Бројем два - оживело-неживе ствари-бића; онтолошка међа коју они прелазе јесте жива и нежива природа а централне фигуре овог подскупа су оживеле статуе и оживели портрети. Тромплеј број три је тромплејски читалац који прелази онтолошку међу између универзума читаоца и универзума (хипер)текста. Овим нисмо исцрпили галерију тромплејских бића. Број одаја у којима обитавају много је већи. Пратећи варијантност ових ликова, застали смо пред пролиферацијом наративих светова које насељавају „дигитална бића”, киборзи, пред надирућом семиосфером новог света - људи у мрежи. Без обзира на варијантност, у нашој номинализацији сви ови јунаци имају сродничке црте. Трансгресивност је једна од особина коју сви деле.

Под тромплејским бићима подразумевамо увек оне који су начинили онтолошки прелаз, „скок/искорак у непознато” и у том скоку остали заглављени. Као такви они не могу бити перспективирани, омеђани једном фокализаторском димензијом те је стога њихова хронотопичност специфична: могу бити у земљи и ван земље подједнако као и на земљи, или на небу; сви који су и тамо и овде, ни тамо ни овде, ни ово ни оно, и ово и оно, трајни лиминари; временски неухватљиви, смештени и у никад и у сада, и у сада и у никад. Увек су на граници, прагу, вратима: бебе пролазе кроз врата утробе, вампири кроз гроб, Илићеве живе статуе (в. песме Тибуло, Мраморни убица) немају видљиво место „прелаза” - оне пролазе кроз додир или поглед који их оживљава. Рушећи међе бића и њихових саморазумљивих светова, праћени нелагодом и неразумевањем, они су увек одбачени изгнаници.

C једне стране, тренутак преласка границе, а с друге, бивствовање у граничном простору - драмске су радње и полови тромплејске драме чији су конфронтирани актери: а) агенси (субјекти) који су у тромплејском свету (вампири, на пример) и б) медијатори (пацијенси) који у њега приступају (жртве). 
Тромплејски светови су драматични, под притиском сусрета изгнаника из природног света, затечених и заточених у тромплејском свету (пацијенса) и субјеката који их и одбијају и привлаче (агенаса). Пацијенси су истовремено и једини медијатори, означитељи јер су субјекти тромплејског света нема бића (мртва, нежива, немогућа). Зато се о тромплејском свету сведочи чешће кроз перспективизацију стања и атмосфере, него кроз именовање.

Граничност и онтолошка међа (жив-мртав, нежив-жив) битни су за одређења тромплејских бића, али нису ињихова differentia specifica.У покушају да разграничимо онтолошки бивалентна бића од оних који прелазе границу али немају тромплејска својства, успоставили смо нову типологију јунака - одвојили смо од тромплејских бића њихове далеке сроднике. То су бића синтезе (Христ, на пример), метаморфична бића (из етиолошких предања, из легенди), али и химерична, хипнотичка, хибернетичка бића (чији је онтолошки статус могућ (самерљив) унутар привилегованог актуализованог наративног света). Тромплејност смо посматрали као скаларну величину која се различитим интензитетом и у различитим манифестацијама испољавала зависно од начина како се успостављао појам границе и граничног бића. Што је граница била семантички и лингвистички непрозирнија, што се нарација показивала немоћнијом да ту границу претвори у језичке симболе, припитоми је значењем (нпр. једно од значења односи се на хришћанску егзегезу постморталног живота у рају и паклу), то је интензитет тромплејског више растао. Тромплејски свет се отварао према неизрецивом и неименљивом, оним што је потискивано, гурано у психотични џеп бића, и што се, будући да је било праћено нелагодом, непрестано преозначавало, саботирало, заустављало. У поређењу са нетромплејским бићима која прелазе границу, у поређењу са бићима синтезе, или метаморфичним бићима која се мењају, или, на пример, хибернетичким (која нестају буђењем), тромплејски јунаци су остајали заглављени опирући се означавању.

\section{Одбрана приче}

Шта се дешава када се ликови „заглаве” у опречним световима, кад доживе тренутак вечности у сусрету с истовремено привлачно-претећим трансцендентним $?^{3}$

Улазак јунака у простор трансцендентног и немоћ да поврати равнотежу и логику природног света, за причу је неподношљиво место које се опире причању - и стога увек неугодна храпавост, муцавост, немост. Наше примере заправо чине наративи у којима се јављају назнаке, сигнали тромплејског не-

\footnotetext{
3 Читање је налажење „ориго тачке” од које почиње оријентација у наративном свету; хијерахизовање „онтолошких” нивоа, препознавање привилегованог света, стварање мотивацијских ланаца који држе на окупу, попут лепка, мотиве. Али шта се дешава када се „овај тепих” измакне читаоцу, када се ликови заглаве у „тромплејском универзуму” у којем се не може реконструисати ориго тачка, препознати привилегован свет, када се не могу хијерархизовати онтолошки нивои и створити мотивацијски ланци? Шта се дешава кад се ликови „заглаве”?
} 
изрецивог света. Ти сигнали се непрестано пригушују, приповедање „хуманизује" и враћа у антропоцентричне оквире разумљивог. Како се причањем пригушују ти сигнали?

Да би се прича наставила, „нема оправдања за неразрешену онтолошку двојност”, приповедач се „враћао” у сигурну луку класичне приче и њених „разумљивих” универзума; нпр., у хришћанским интерпретацијама одвајају се бића раја од бића пакла, живи од мртвих - праве се границе које омогућавају именовање преко разлика, класа, просторних или временских одсека, категорија и сл. Религијским наративима су се слабили сигнали неизрециве Другости.

Повратак у луку класичне приче, прелаз од асимболичног у симболично, привукао је пажњу особито проучавалаца неприродних наратива. Служећи се једном од најзначајнијих вампиролошких монографија у српској књижевности (Мотив вампира у миту и књижевности Ане Радин), навешћемо механизме дистанцирања од тромплејског наратива пратећи типове транспозиције вампирског мотива у српској прозној књижевности. Они су истовремено и механизми дезаутентизације тромплејских светова (њиховог измештања из могућих у немогуће светове). То су:

1. удвостручавање приповедне опције (увођењем два приповедача од којих је један „објективан” и оспорава постојање натприродне појаве, а други „субјективан” те га не доводи у питање)” (Радин, 1996: 15-16);

2. „избор лабилног јунака за протагонисту догађаја (јунак ком се под утицајем застрашујућих прича и сопственог сујеверног убеђења само привиђају натприродне појаве којих иначе нема)" (Радин, 1996: 15-16);

3. „онеобичавање простора и времена (тако да замагли стварност и дозволи грешку у процени појаве)" (Радин, 1996: 15-16).

Наведене примере дезаутентизације тромплејског света можемо тумачити и кроз процесе рационализације, покушаје логичког ума да супротстави природан свет (као привилегован) неприродном. У том случају, у форми претпоставки, објашњења, алогички свет се „подређује” антропоцентричној логици приповедања а тромплејским јунацима конфронтирају привилеговани јунаци, конструктори поузданог света. Борба неизрецивог са причом и победа приче заправо је трикстерска замка тромплејских наратива, приповедачевих „техника”, „умећа”, „лажи” у пригушивању сигнала неизрецивог, истовремено и привлачног и одбојног непознатог.

Шта је све морао савладати приповедач трикстер - и како је, слабећи сигнале једног, појачаво сигнале свог нарцистичко-антропоцентричног аутокомуникативног света?

Тромплејске јунаке је стварао кроз негације и инверзије: наспрам миметичног успостављао антимиметички концепт, наспрам природног - неприродни, наспрам могућег - немогући. То је већ било довољно за драму, за причу и причање, за прво припитомљавање неприпитомљивог света. Издвојили 
смо неколике одлике новоконструисаног тромплејског света: антимиметичност, протежност, зазорност, парадоксалност и амбивалентност.

Тромплејски јунак је антимиметичан: он није као ми, нити је бољи нити гори од нас. За почетак, не може се чак одредити ни као рођени или нерођени, живи или мртви, неживи или живи. У појмовној апаратури Шкловског он би увек био онеобичен јунак, у Бартовој - атопичан.

Неомеђеност тромплејских јунака условила је и њихову неприродну физичку појавност, парадоскалност ерототанатичног споја: истовремену неограничену екстензивност и пунктуалност. Тромплејска бића се протежу кроз светове мртвих и живих, али су и пунктуална бића њиховог споја; истовремено су бића велике екстензије (бесконачног и вечног) и мале екстензије (заглављена у тренутку, у неподношљивом споју и живог и мртвог, ни живог ни мртвог). Динамична екстензија омогућава ширење и скупљање бића: оно може бити статуа-жена, мртвац-љубавник, читалац и прочитан, може постојати у некомпатибилним али „коегзистирајућим облицима” (о коегзистирајућим и некомпатибилним варијантама в. Иверсен 2013, Аблер, 2013). Битна одлика (коегзистирајућих) тромплејских бића је парадоксалност. Парадокс оптимализује ширење бића, прекорачивање међе (онтолошких, психолошких, логичких баријера лика).

Управо због ове парадоксалности која одликује тромплејске јунаке у дескрипицији наративног света функционалнијом се показала неприродна наратологија и њена поетика опонирања „природним” наративима. ${ }^{4}$ У концептуализацији тромплејских бића класична миметичка теорија лика испоставила се недовољном и слабо употребљивом. Несамерљиви копулом „као”, вампири или оживеле статуе нису се уклапали у еталонску дескрипцију лика коју нуди класична наратологија. Искључивост, спој неспојивог, била је тачка њиховог бујања. Неприродна наратологија се показала инспиративном за анализу тромплејских наратива не само на плану дескрипције већ и њихове реторике.

\section{(Не)моћ реторике и тромплејско биће}

Реторика тромплејских наратива почива на фигурама (карактеристичним за неприродне наративе): на негацијама, инверзијама, парадоксу и хипербатону. То су типичне фигуре којима се кроз негирања или искључивања познатог покушава савладати нелагода непознатог. Други начин описивања

\footnotetext{
${ }^{4}$ Најпрецизнији опис тромплејских наратива пронашли смо у неприродној наратологији под лексикографском одредницом „неприродни наратив”: „An unnatural narrative violates physical laws, logical principles, or standard anthropomorphic limitations of knowledge by representing storytelling scenarios, narrators, characters, temporalities, or spaces that could not exist in the actual world" (Јан Албер, https://www.lhn.uni-hamburg.de/node/104.html). Тромплејски светови чине један од подскупова неприродних светова. И за наративне светове који се плету око вампира или оживљених кипова (као и за неприродне наративе) такође је карактеристично нарушавање психичких закона, логичких принципа или стандардних антропоморфних ограничења знања у презентовању јунака, простора или времена који не би могли да постоје у актуалном свету.
} 
односи се на стање бића које улази у неименљив страни свет непознатог и претећег Другог.

Најсажетије описе специфичног стања кроз које пролази пацијенс уласком у тромплејски свет нашли смо у етнолошкој литератури у описима обреда прелаза (лимеса - прага у којем обитавају лиминална бића), као и у студијама из неприродне наратологије.

У студији Варијащије на тему лиминалности Виктор Тарнер наводи следеће карактеристике лиминара:

Они су пола-пола од успостављеног стања политичко правне структуре. Такође измичу уобичајеној когнитивној класификацији, јер нису ни-ово-ни-оно, ни-овде-ни-тамо, ни-онакви-ни-овакви. Гледано из њиховог неземаљског, структуралног контекста, они су на неки начин мртви за овај свет, јер лиминалност има многе симболе смрти [...] Може се рећи да они учествују у процесу где се мрве у прах неке врсте хомогеног друштвеног материјала у којем се могућности диференцијације још увек могу назрети (Тарнер 1986: 41).

Сличне варијације на тему лиминара налазимо и у раду Барбаре Мајерхоф Обреди прелаза: процес и парадокс: „Особа у лиминалној фази представља неиздиференцирану људскост: све што је универзално, урођено, целовито и сједињено” (Мајерхоф 1986: 24).

Искуство „неиздиференциране људскости” кроз које пролази пацијенс/ иницијант покушали смо да објаснимо довођењем у везу са стањем, које Јулија Кристева у књизи Моћи ужаса - огледи о зазорности именује као зазорност. Она пише о „сплету афеката и мисли” који преплављују човека и побуни против нечега прекомерног што долази из спољашњег или унутрашњег света, нечег што је близу, али је неприхватљиво, о зазорљивом које је нећудоредно, тамно, заобилазно, дволично. Ипак, она уочава и амбивалентну страну зазорности, насупрот одбојности - пол привлачности:

Но истодобно је тај полет, тај грч, тај скок привучен нечим исто толико замамним, колико и забрањеним другдје. Неуморно, као због каква неукротива бумеранга, налази се онај који је тиме обузет, због пола позивања и одбијања, дословце, изван себе (Кристева б. г. 7).

Као бумеранг, и тромплејска бића (агенси) истовремно привлаче и одбијају или су, ван себе, истовремно привучена и одбијена (пацијенси). Аналогија се може успоставити и са Ничеовим описом понора који мами онога који гледа у њега или Твитчеловим описом живих мртваца. У студији Живи мртваци Твитчел пише о добровољном пристајању на поглед у онострано, на подметање грла за угриз вампира - о привлачној (не само одбојној снази) претећег трансцендентог, о покорности и послушности жртве. Будући да су тачке ерототанатичног спајања (смрти и рађања), тромплејска бића поседују „еротизирану зазорност” (Кристева б. г. 32) - неугоду чији је пол угода спајања у којој је идентитет одсутан. 


\section{Хронотоп. У тмини и немости нових светова}

Тромплејски јунаци долазе из небића, из другости која нам недостаје, која је и понор и мост преко наше остварене фиксираности. Њихов свет није перцептивно савладив чулима јер је у смрти, слепилу и немости/глувоћи.

Ноћ је најчешће „светло” тог света (,Зазорност чува ону ноћ у којој се губи обрис означен ствари и у којој делује тек наизмерљив афект" (Кристева 2019:18), а тромплејски јунак у њему је, како Кристева у књизи Моћ ужаca описује, зазорљиво биће, „путник у ноћи чији крај стално измиче”, који „осећа опасност, пропаст коју представља псеудо-објекат који га привлачи” (Кристева 2019: 16).

Тромплејски пацијенси су увек дезоријентисани - без часовника који куца у њиховом свету, без биолошког времена и његових граничних полова рађања и умирања. Њихово време је и прекомерност бесконачног, и тренутак прекорачја из коначног. Оно је зазорљиво „двостурко”(„Време зазорности је двоструко: време заборава и грмљавине, копреном застрте беконачности и тренутка у којем се јавља откровење” (Кристева б.г. 16).

Ноћ у којој се губе обриси означених ствари и слепило света који се опире означавању уводе нас у тромплејски простор и време несагледиво у биолошким просторно-временским координатама. У студијама из неприродне наратологије онеобиченом (тромплејском) времену придато је својство ширења, скупљања, потирања, премештања (в. Албер, Unnatural Narrative). У оваквим хрономонтажама могуће су обрнуте последично-узрочне релације, временске рупе (у којима не постоји хронометријско време), контрадикторне темпоралне линије „које се састоје од међусобно искључивих догађаја или низова догађаја"); диференцијалне временске линије (у којима становници истог света старе другачијом брзином од осталих) (в. Alber, Unnatural Narrative). У географији која је карактеристична за неприродне наративе и која не може бити актуализована у реалном, природном свету („non-actualizable geographies”), дезоријантисаност се постиже инверзивним релацијама горе - доле, лево - десно, унутра - ван; (синдром Алисе у земљи чуда). Тромплејски време-простор не подлеже физичким законима. Близак је „фантастичном хиперболизму времена” који, по Бахтину, карактерише растезање часова, сажимање дана, месеци или година у тренутак. Такав је случај, на пример, чест у катабазичним наративима, као што је у нашем примеру проток времена у приповеци Вечност Јанка Веселиновића или Секунд вечности Драгутина Илића.

У тромплејском универзуму кључан је тренутак неподношљиве онтолошке двојности бића у преступу. То је тренутак који трансцендира физичко време и физички простор и „излази” из хронолошког узрочно-последичног следа. Две најчешће дезоријентишуће просторне фокализаторске опције које смо препознали у тромплејским наративима су:

a) парализован простор (заснован на емотивној спацијализацији: дефинисању места преко емоције страха, нелагоде, непријатности), 
б) „земљотресно (еуфорично) тло” ерототанатичног нестајања-настајања у коме се губи упоришна идентификацијска самеравајућа тачка субјекта.

Попут времена, можемо закључити да је и тромплејски простор зазорљив „заокупља одбаченика, изопћеника, никада није један, ни хомоген, ни обухватљив, него битно дјељив, савитљив, катастрофичан” (Кристева 1989: 15).

Зазорљив у својој двостукости је и простор на слици Пере Борељ дел Каса која нам је и послужила као инспирацијски замајац; дечаку који бежи од критике искорак у нови свет, наш свет с оне стране сликаног, као да није донео олакшање. Управо обратно - делује да је оно ка чему бежи страшније од онога од чега бежи и да му не пружа утеху. У његовом погледу је страх од Другог који га гледа, који је заправо огледало нас са друге стране рама. Ми постајемо субјекти неизрециве неутешне Другости.

Будући да не постоји континуитет времена и простора, не може се сусрет с трансцендентним припитомити „искуством” пацијенса, нити се може пренети; сваки сусрет с тромплејским бићем је рискантан, смртоносан, непоновљив. Тромплејски наративи почивају на аномалији (,anomalous suspense” - Албер), на неизвесности која се не смањује репетицијом (,paradox of repeated suspense" - Албер)5. Уместо уобичајног попуштања напетости, сваки расплет је лажан и сваки расплет је клица новог заплета, пример метасуспензије. Тромплејски свет је претећи присутан у својој могућности чак и кад га дневна светлост руши. Ноћ без обриса је сенка која се надвија над сваком ,јасном” контуром дана.

Наша анализа тромплејског наратива имала је два смера - с једне стране, циљ нам је био да препознамо механизме слабљења тромплејских сигнала и „одбрану приче” од неизрецивог, некомуникативног трансцендентног, а с друге, да их упркос тим механизмима (негације, рационализације, парадокса) чујемо. У потрази за причом о Другом, испоставило се да смо, пишући о онтолошки бивалентним бићима, заправо писали о доминантним страховима - од људског несвршеног карактера, од губика Другог, од погрешених представа о свету и себи у свету, од лажности чулног, искуственог. Нисмо ли тиме, пишући о фантастичним немогућим небићима, отворили „пандорину кутију” - „психотички џеп” у коме скривамо истине и непознанице о себи. И није ли фантастика прича о оном што јесмо, а не о ономе што нисмо, скривени, помало аветињски, психонаратив нас самих опетованих у немогућим или алтернативним световима.

\footnotetext{
${ }^{5}$ В. Албер: J. Alber, Unnatural narrative, https://www.lhn.uni-hamburg.de/node/104.html.
} 


\section{ЛИТЕРАТУРА}

Албер 2014: J. Alber, Unnatural narrative, https://www.lhn.uni-hamburg.de/ node/104.html, preg. 22. 09. 2020.

Бодријар 1994: Ж. Бодријар, О завођењу, Подгорица, Приштина.

Долежел 1997: Л. Долежел, Мимезис и могући светови, Наративни светови, Реч, 4, 30, Београд, 74-83, 83-88.

Кристева 1989: J. Kristeva, Moći užasa. Ogledi o zazornosti, Zagreb: Naprijed. Кристева: J. Kristeva, Ужас, Београд: Арт прес, б. г.

Majerhof 1986: Б. Мајерхоф, Обреди прелаза: процес и парадокс, Градина, 21, бр. 10, 18-39.

Тарнер 1986: В.Тарнер, Варијације на тему лиминалности, Градина, 21, 10, $40-56$.

The living handbook of narratology. Hamburg: Hamburg University. URL $=$ http:// www.lhn.uni-hamburg.de/, preg. 22. 09. 2020.

Dragana B. Vukićević

„TROMPE L'OEIL” BEINGS OF FICTION

Summary

This paper is about trompe l'oeil beings but not in painting than in literature. We wrote about revived statues and revived dead as impossible ontological bivalent heroes. We found the most inspiring descriptions of impossible beings in studies in unnatural narratology, as well as in ethnological explanations of the rite of passage. They cannot be placed in typical spaces or in the usual biological time. They are both alive and dead, neither alive nor dead, that separates them from other heroes. 